\title{
WHY WE SHOULD TALK? THE POTENTIALS OF COMMUNITY DIALOG IN GROUNDING AN INTEGRATED RURAL DEVELOPMENT
}

\author{
Adi Suryani $^{1}$, Soedarso $^{1 *}$, Endarko $^{2}$, Ahmad Muklason $^{3}$ \\ 1 Fakultas Desain Kreatif dan Bisnis Digital, Institut Teknologi Sepuluh Nopember, Surabaya, \\ Indonesia \\ 2 Fakultas Sains dan Analitika Data, Institut Teknologi Sepuluh Nopember, Surabaya, \\ Indonesia \\ 3 Fakultas Teknologi Elektro dan Informatika Cerdas, Institut Teknologi Sepuluh Nopember, \\ Surabaya, Indonesia \\ * Corresponding author: E-mail: soedarsoits@gmail.com
}

Citation: Suryani, A., Soedarso., Endarko., and Mukhlason, A. 2020. Why we should talk? The potentials of community dialog in grounding an integrated rural development, J. Asian Rur. Stud. 4(2): 154-177

\begin{abstract}
Rural development is a social process. It involves local community in all stages of development. Community dialog is a means for facilitating community involvement in determining a development direction, potential development plan and development sustainability in the future. Frequently, local community is considered as the development target. This position puts them just being development watchers, spectators, silent and passive recipients. Moreover, these silent roles make them remain unempowered since they do not know how to determine their future, how to take part in collective decision and feel being neglected. This study examines potentials of community involvement in dialog. A qualitative research paradigm is adopted. The data are collected by recording, transcribing and analyzing community dialog at Klagen, Nganjuk, Jawa Timur. The study finds that community dialog offers considerable potentials. The first potential of community dialog is generating local community commitment, awareness, sense of belongingness and supportive character to build their own homeland. These positive development psychological states, characters and ethos are soft human dimensions which can be critical drivers in rural development. The second is creation of local knowledge and scientific knowledge joint enabling innovation and collective learning process. This joint-knowledge allows the combination of local wisdom and scientific insight. The third is building shared or collective development vision and plan. This plan and vision allow the development prioritizing process and development of rural strength, potential competitive advantage and resource building. The fourth is expanding rural networking and exercising rural people capacity to build wider internal and external social relationship.
\end{abstract}

Keywords: community dialog; rural development; local knowledge; rural networking; vision; plan

\section{Introduction}

Community participation and engagement are required in development at all of its' stages: planning, execution and sustaining. A region development that is initiated topdown without considering local fitness contexts, without involving the local community to engage and participate and without educating the targeted society to be self-reliant and self-developed, is likely to unsustain. 
Local community is an invaluable human resource in development. Their local insights, including social cultural, environment, nature instinct, traditional skills and wisdoms are vital asset and investment for tacking local issue and enabling development. Furthermore, the local community development mindset, behavior, attitudes, commitment, awareness, sense of community and change of readiness are the vital human software for development facilitation. Thus, local community roles are genuine local developers since they potentially occupy various determinant roles in development. They can be need analysts, initiators, planners, executors and sustainers of development.

One of many approaches to promote local community contribution in development is through local community dialog. Many studies explore roles, promises and benefits of community dialog for development in different angles (Filomeno, 2019). Community dialog is a tool to support development and a strategy to generate community engagement (Wallerstein \& Bernstein, 1994). It is a technique for solving community issues (Anetzberger et al., 2004; Coyle, 2016; Ounvichit \& Yoddumnern-Attig, 2018; Wegs et al., 2016). Numerous rural development studies explore the effectiveness of community dialog (Figueroa et al., 2016), its challenge, peril and tension (Chen et al., n.d.), process, rules and procedures for guiding constructive dialog (Holloway, 2014), power relations in dialog (Mercer-Mapstone et al., 2019), dialog viewed from the communication perspective (Pearce \& Pearce, 2000), role of dialog in local-social capital (Meinzen-Dick et al., 2004), dialog as a tool for integrating local knowledge (Richards, n.d.) and dialog roles in policy design, especially for the underserved community (Beck et al., 2002). In spite of numerous studies on community dialog, how rural community engages in a dialog for initiating a smart village building remains unexplored widely. Thus, this study aims to examine the promises of community dialog towards Klagen smart village, particularly at the initial stage of development. It is expected that the findings can fill the gap and enrich understanding and knowledge on rural local community engagement in development. It is also expected that rural community empowerment through community dialog can encourage them to attain better living, especially through an integrated rural development. This integrated rural development is constructed as an ongoing development process which involves collaboration of external intervention and local aspirations to improve rural community livelihood, preserve rural values through resource distribution, minimize comparative disadvantages and innovate rural resource (Nemes, 2005, p. 23). The implementation of integrated rural development is supported by the employment of integrated rural development systems which integrate and coordinate social network, administration, knowledge decision making systems and information in a coherent structure (Nemes, 2005, p. 23). This paper adopts an integrated development paradigm as a central perspective in understanding and examining smart village building initiative at Klagen, Nganjuk, Jawa Timur.

\subsection{Community dialogue and sharing}

Recently, the participatory and bottom-up approach in developing rural is widely proposed and recommended to synergize community and act collectively. It is widely examined by rural development studies that local people participation is a necessity to 
ensure development process and its sustainability. Community active participation is a fundamental pre-requisite of development (Ounvichit \& Yoddumnern-Attig, 2018).

Community dialog is identified as a participatory strategy which generates multibenefits for rural development. Dialog is a conversation conducted intentionally to increase understanding, target certain issues, inquire thoughts and actions which differs from debate since dialog is focused to build relationship among the participants in order to collectively explore the targeted issues (Romney, n.d., p. 2). Dialog can be attended by just five people in roundtable setting to five hundred people in a large civic (Beck et al., 2002, p. 30). Relational issues are likely to be neglected in dialog since it highlights the process of thinking together (Pearce \& Pearce, 2000, p. 414). It is a form of communication as the primary social process (Pearce \& Pearce, 2000). Dialog represents an ethical communication which considers public voices and values joint creation and decision making (Kent \& Taylor, 2002, cited in Chen et al., n.d.). Dialog is not only communication arena among brotherhoods, but also a means to reach agreement, facilitate discussion and establish communication without pressuring (Johnson, 2002, p. 1). Dialog is a part of social change process (Wheatley et al., 2012, p. 3).

Community dialog serves various functions. Community dialog facilitates community collective action (Ounvichit \& Yoddumnern-Attig, 2018, p. 369), increases community engagement and participation (Capizzo, 2018; Mercer-Mapstone et al., 2018). It promotes relationship building, trust and fairness impacting on social acceptance (Mercer-Mapstone et al., 2018; Park \& Kang, n.d.). A company-community dialog is a means to obtain social license and implementation of social democracy (Mercer-Mapstone et al., 2018, p. 675), coordination (Pearce \& Pearce, 2000) and collaboration (Filomeno, 2019, p. 2). Community dialog brings together all stakeholders' knowledge and their expertise (Anetzberger, Ishler, Mostade \& Blair, 2004, cited in Woolrych et al., 2015, p. 239). The effectiveness of community dialog process is enhanced by transparency and engagement, learning orientation and contextualizing knowledge within community (Minkler \& Wallerstein, 2010, cited in Woolrych et al., 2015, p. 239). Community dialog is potentially allowing power redistribution, community engagement and social license (Mercer-Mapstone et al., 2019, p. 191). Informed understanding of different views and decision making focusing on solution-seeking can be attained through community dialog (Coyle, 2016). Community dialog is a means for deliberative engagement, developing democracy and acknowledging civic knowledge (Coyle, 2016, p. 235), generating participatory democracy, democratic deliberation and providing basis for social policy (Bonham et al., 2009, p. 5). It facilitates community voices expression, interests and expectations elicitation (Bonham et al., 2009, p. 11). Community dialog opens up the gate for executing planned community program through communication facilitation (Wegs et al., 2016). Dialog is also an education tool (Barrow, 2010), deliberative democratic education, pedagogy, and community education (Longo, 2013). Community dialog is a part of deliberative pedagogy since it provides conversation space for community to connect and transform based on their real life situation (Longo, 2013, p. 5). Community dialog promotes collective communication, builds conjoint agreement through shared, genuine discourse and culture creation (Laszlo \& Laszlo, 2005). Community dialog has normative, substantive and legitimate functions. Normatively, dialog is a forum for 
enforcing community right to participate, substantively it can improve the decision quality and instrumentally, dialog increases legitimacy and eases implementation of decision (Parker \& Duignan, n.d.). Community dialog addresses community concerns in the process of community building (Beck et al., 2002), facilitates interrelationship and better understanding on targeted community, develop achievable plan and strategies to fit community concern (Beck et al., 2002, p. 38). Community dialog benefits in generating stakeholders' perspective taking, acknowledging diversity, increasing interaction and communication and strengthening commitment for action (DeTurk, 2006; Wheatley et al., 2012), mitigating conflict (DeTurk, 2006, p. 49), ending disputes (Holloway, 2014) and minimizing risks (Mercer-Mapstone et al., 2019, p. 194).

Several studies examine the supporting elements of constructive community dialog. A fruitful community dialog is grounded on collective concern on socio-ecological relations, the need for joint management and understanding of common management principles (Ounvichit \& Yoddumnern-Attig, 2018). Progressive community dialog needs effective communication, dialog facilitators who have a broad range of knowledge and skill (including knowledge on sustainable development, communication and common management), neutrality, conflict management, reason-based thinking (Ounvichit \& Yoddumnern-Attig, 2018). The Mayor's Office of Immigrant and Multicultural Affairs of Baltimore City (MIMA) defines several components of effective community dialog, including participants' equal status, organizational support, common goals, participants' cooperation, individual readiness, varied and repeated contact, continuous dialog, dialog rules, participants' potential friendship and dialog meeting duration (Filomeno, 2019, p. 4). Meaningful engagement in community dialog requires dialogue participants' capacity to be able to comprehend information, communicate effectively and solve conflict, inclusivity and diversity (Mercer-Mapstone et al., 2019). Community dialog can be enhanced by participants' technical information, communication skills, education and conflict management (Mercer-Mapstone et al., 2019, p. 196). Trust, positive relationship, reciprocal understanding, shared decision making and common goal can promote constructive dialog (Mercer-Mapstone et al., 2017, cited in Mercer-Mapstone et al., 2019, p. 197).

\subsection{Rural Development: Its' Ground and Changing Paradigm}

Rural development paradigm is shifting today. Formerly, rural is the backbone and agricultural supplier for urban. Currently, rural areas are occupying multi-roles. They are servicing agricultural needs, becoming centre of business, opening creative home industries and developing eco-tourism. This demonstrates that rural are not dependent to urban anymore.

Through rural development process, it is expected that rural community well being can be improved. Rural communities are frequently stigmatized as unwell being, poor and suffer from inequality (Kay, 2009, p. 104), vulnerable and deprived (Bayes, 2001, p. 4). Rural living welfare is likely to be obstructed by resource-type disadvantages which impede rural people from communication access, suffer from limited infrastructure facilities, restrict communities' ability and resources to produce goods and services (Nemes, 2005, p. 12). Rural development is understood as an effort to benefit rural populations by sustainably improving rural people's welfare and living standards (Anríquez \& Stamoulis, 2007, p. 2). However, rural development is not only 
the matter of improving rural people's economic capacity, but also empowering people and building community's self-control, destiny determination and threat-coping capacities (Shortall \& Shucksmith, 2001, p. 123). Rural development involves complexities of multi-levels, multi-actors and processes (van der Ploeg et al., 2000, p. 1). Rural development relates to agriculture-society interrelation in global context, a changing paradigm of agriculture, individual farm household, roles of countryside and economic actors and interlinked practices (van der Ploeg et al., 2000, p. 392). Today's rural roles are changing due to the global warming, food crisis and deforestation (Kay, 2009, pp. 103-104; Maxwell et al., 2001).

The new paradigm of rural development views rural as not always associated with farming. Enhancing agricultural activities only cannot eliminate rural poverty (Ellis \& Biggs, 2001; Mack et al., 2005) since rural poverty is caused by rural over dependence on agricultural income and production (Bayes, 2001, p. 2). This new paradigm emerges many arguments, ways and approaches to potentially develop rural communities. Crosssector and diverse rural occupations may potentially and effectively decrease rural poverty in the future (Ellis \& Biggs, 2001, p. 445). Even though one activity cannot alleviate rural poverty, livestock and poultry are still suggested as the dominant sector in rural development (Mack et al., 2005, p. 8). Farming is still regarded as an integrative and a major element in newly emerging rural development model. This new emergent development model provides a basis for farm enterprise growth, mobilization and resource diverse utilization (van der Ploeg, 2000, p. 502). Multifunctional agriculture remains the major element in rural development (Kitchen \& Marsden, 2009b, p. 279). Rural development can be intervened through various sectors: land consolidation (Pašakarnis \& Maliene, 2010), education (Atchoarena \& Gasperini, 2003, p. 56), ecological modernization, social structures, governments, business and market transformations (Marsden, 2004, cited in Kitchen \& Marsden, 2009a, p. 276), natural resource-related development basis, including economy diversification, tourism and biodiversity economical use (Fabricus et al., 2004, p. 13), natural resource management development (Fabricus et al., 2004) which is consisting of resource renewal, quality of life management, management of livelihood and management of participatory resource (Bruckmeier \&Tovey, 20008), non farm economy activities (Anríquez\& Stamoulis, 2007; Ashley \& Maxwell, 2001; van der Ploeg \&Roep, 2003) or "pluriactivity" (van der Ploeg, 2000), rural tourism (Ashley \& Maxwell, 2001, p. 410; van der Ploeg, 2000), small-and medium-scale farm-based enterprises (van der Ploeg, 2000), energy use (Cabraal et al., 2005), entrepreneurship and innovation, especially using agricultural commodities (Gale, n.d.; Nemes, 2005), agriculture-industries synergy (Kay, 2009), ecological economics, eco-system services and ecological modernization (Kitchen \& Marsden, 2009a).

\section{Method}

This study aims to explore the potential promises of community dialog in promoting Klagen smart village development, especially at the initial stage. The dialog is established between Klagen local community and an external developing agent from a higher education institution (Figure 1). 


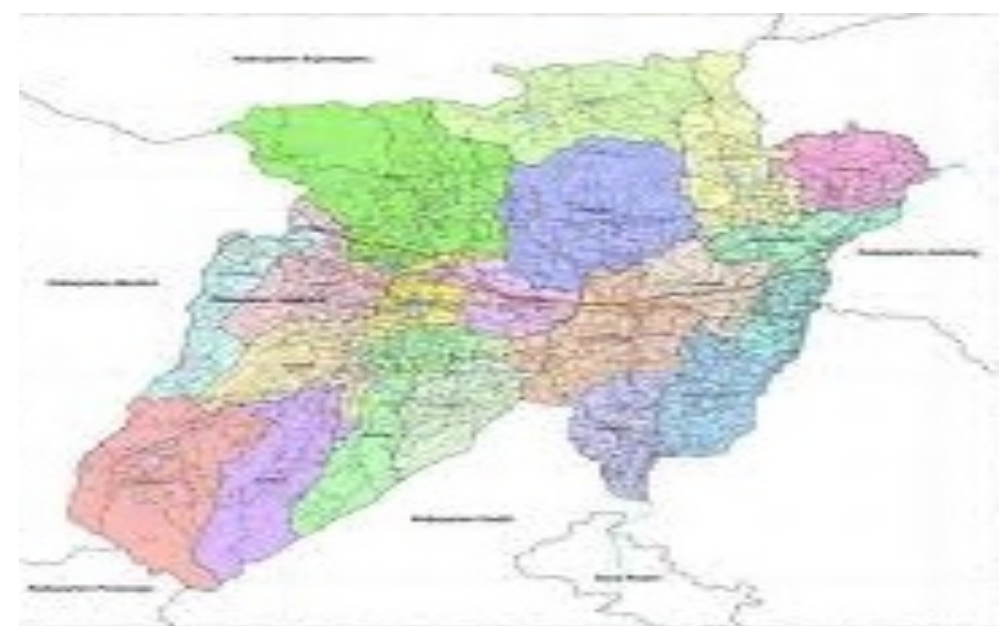

Figure 1. Map of Klagen location (source: eprints.umm, n.d.)

The initiative of smart village which rapidly flourishes and becomes a new trend in Indonesia is relevant to the new paradigm of integrated rural development. A smart rural is not only relying its' growth on agricultural commodities, but also multidevelopment activities on the basis of agriculture/farming, for instance entrepreneurship, technology, business, energy, tourism (Anderson et al., 2017; Fennell et al., 2018; Prinsloo et al., 2017; Shukla, 2016). A smart rural is associated with both community as agricultural producers and community as entrepreneurs, innovators, selfempowered and resilient people (McManus et al., 2012; Phahlamohlaka et al., 2014; Ristianti, 2016). Smart village is developed by incorporating multi-components of smart environment, mobility, economy, living, governance and people (Santoso et al., n.d., p. 14), smart energy, connectivity, agriculture, education, health, environment and infrastructure (NIRDPR, n.d.). Recently, many villages in Indonesia start to transform themselves into smart rurals (Subekti \& Damayanti, 2019) as an attempt to adapt to the globalization changes and 4.0 industrial revolution (Santoso et al., n.d.). The needs to reduce unemployment, eliminate poverty, increase economic condition and empower its' community members are the impetus of Klagen community to collectively initiate to develop their village.

The research is conducted as an integrated component of community service program at Klagen. Klagen is located at KabupatenNganjuk, JawaTimur. Corn, red onion and coconut are its' main agricultural commodities, while its' poultry sector is developed through duck breeding (Kementerian Dalam Negeri Republik IndonesiaDirektorat Jenderal Bina Pemerintahan Desa, 2019). Demographically, the majority of Klagen population's occupations are farming and working at private institutions. In educational sector, the majority of Klagen population are only graduated from the primary level (1.772 persons), while there is only 1 person holds doctorate degree (Kementerian Dalam Negeri Republik Indonesia-Direktorat Jenderal Bina Pemerintahan Desa, 2019). Klagen has several facilities and infrastructures to support its' development, including local government office, health facilities (puskesmas, posyandu), schools, praying facilities, transportation, clean water, irrigation, sanitation and sport facilities (Kementerian Dalam Negeri Republik Indonesia-Direktorat Jenderal Bina Pemerintahan Desa, 2019) 


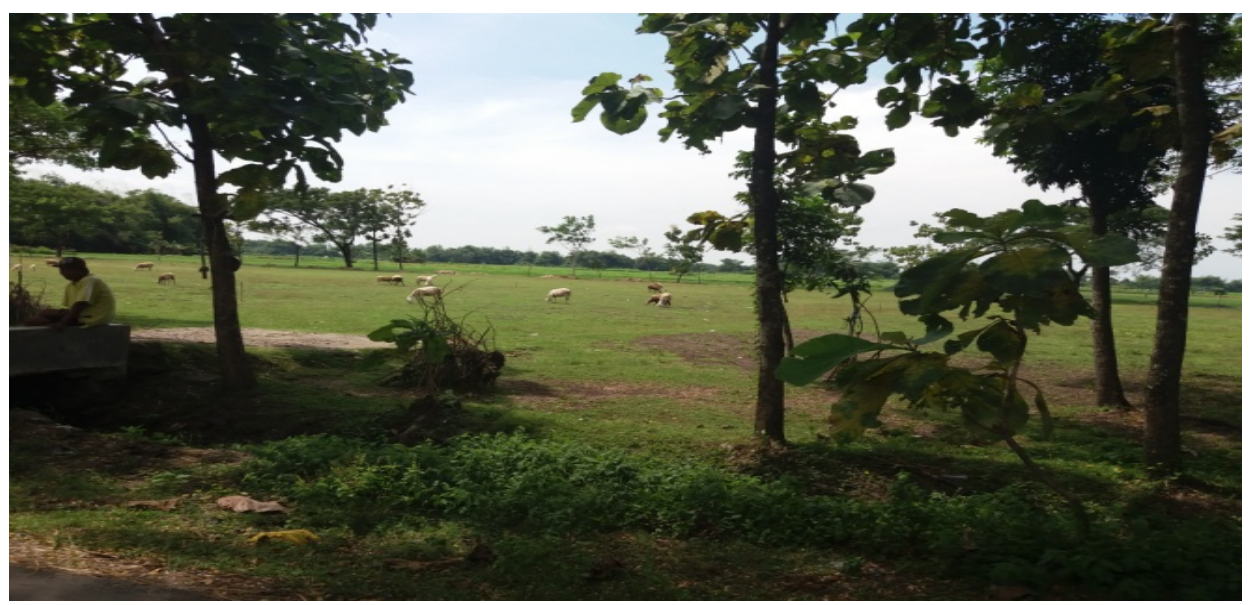

Photo: an open space/field at Klagen

The study adopts qualitative method. A qualitative method can be applied to observe collective action, how a collective people implement shared decision or process of changes by using variety of data collection techniques, participant observation, case studies, interviews, focus groups and oral histories (Meinzen-Dick et al., 2004, pp. 1516). The research participants are several representatives of Klagen, including head of village, secretary, treasurer, some senior members including migrated ones, elders and karangtaruna (youth association). The data are collected through direct natural observation during dialog process with Klagen community. The researchers participate in the dialog as the external developing agents. During the data analyzing process, the recorded data are transcribed and classified based on the emerging themes. Subsequently, the classified data are analyzed by describing, interpreting their meaning and linking to the existing studies. Steps/agendas of Klagen community dialog is represented in the following table (Table 1)

Table 1 .The Agenda and purposes of Klagen community dialog

\begin{tabular}{|c|c|c|}
\hline No. & Agenda/Activities & Purposes \\
\hline 1. & Silaturahmi & Visiting Klagen for building familial/brotherhood relationship \\
\hline 2. & Welcoming & $\begin{array}{l}\text { Pak Kades Klagen (head of village), as the representative of all local } \\
\text { dialog participants, welcomes the community service team }\end{array}$ \\
\hline 3 & Self-introduction & $\begin{array}{l}\text { Both parties, Klagen representatives/dialog participants and community } \\
\text { service team introduce themselves }\end{array}$ \\
\hline 4. & Opening talk & $\begin{array}{l}\text { Is delivered by Pak Kades, revealing recent condition at Klagen, issues } \\
\text { relating to economic, public services, facilities/infrastructures, and } \\
\text { population }\end{array}$ \\
\hline 5 & $\begin{array}{l}\text { Hearing and } \\
\text { spontaneous dialog }\end{array}$ & $\begin{array}{l}\text { All of Klagen participants reveals issues emerging at Klagen, from their } \\
\text { daily life natural observation/real situation, express their ideas to develop } \\
\text { Klagen, commitment, willingness, expectation and enthusiasm to develop }\end{array}$ \\
\hline 6 & $\begin{array}{l}\text { Dialog with karang } \\
\text { taruna }\end{array}$ & $\begin{array}{l}\text { Karang taruna members convey issue relating to youth, youth } \\
\text { entrepreneurship and required facilities needed to support youth } \\
\text { enterprises }\end{array}$ \\
\hline 7 & Agreement & Planning and shared commitment reinforcement \\
\hline 6. & Closing & Relaxing and eating pisang goreng, ketela goreng \\
\hline
\end{tabular}




\section{Results and Discussion}

The study shows that community dialog can potentially facilitate development process and prospective development sustainability since it involves the impacted community to contribute, express voices on what and how they want to develop, reveal feelings on what they are worry about, opens chances to determine their own future. Klagen community inclusion in dialog allows them be development partners, instead of passive recipients. The data prove that community dialog benefits development grounding process in several aspects: commitment and awareness building, jointknowledge development, vision and plan building and networking.

\subsection{Building Commitment and Awareness to Develop}

Rural development is a social process which needs collective action of the impacted community. To execute a development program progressively and sustainably, active participation of local community is required. The data show that community dialog is the ground for generating community supportive psychological states, ethos, behavior and mental to develop. These software of people as human capital are fundamental for development. People attitude towards development determines successful development (Kuyan, 2010, cited in Aguila \& Ragot, 2014, p. 25). The data indicate that community dialog can be a means for generating, increasing, reviving and spreading development spirit and commitment.

Table 2. Community Commitment and Awareness

\begin{tabular}{|c|c|c|}
\hline No. & $\begin{array}{c}\text { Dialog } \\
\text { Participant }\end{array}$ & Data extract \\
\hline \multirow[t]{4}{*}{1.} & DP-1 & $\begin{array}{l}\text { "I expect that there will be improvement for our village. Our village becomes more } \\
\text { prosperous than other villages..." (DP-1-1) }\end{array}$ \\
\hline & & $\begin{array}{l}\text { "...even though we just can finish our education at the secondary levels, we expect that } \\
\text { our children can at least continue their study at tertiary level..." (DP-1-2) }\end{array}$ \\
\hline & & $\begin{array}{l}\text { "...it will be better if we can develop this activity, and we ask karang taruna to be } \\
\text { involved..." (DP-1-3) }\end{array}$ \\
\hline & & $\begin{array}{l}\text { "... and the other important thing is togetherness of all village community to develop, } \\
\text { such as village tourism. We actually have already started it by planting cavendis banana } \\
\text { at PakYudi area..." (DP-1-4) }\end{array}$ \\
\hline 2 & DP-2 & $\begin{array}{l}\text { "...in the future, we want to solve this problem. Next, we want to open a centre or an } \\
\text { office for local people to come and borrow some money for their family enterprise..." } \\
\text { (DP-2-1) }\end{array}$ \\
\hline 3 & DP-3 & $\begin{array}{l}\text { "...in general we know the character of our community. We are part of community who } \\
\text { interact with people in the field daily. We understand how to socialize with them. We try } \\
\text { to move them, let's develop..." (DP-3-1) }\end{array}$ \\
\hline \multirow[t]{2}{*}{4} & DP-4 & $\begin{array}{l}\text { "...to be honest, I personally expect that we open a new life, especially for today } \\
\text { generation...don't inherit the past failure... a failure at our generation. I mean, we hope } \\
\text { it's just us who feel the bad impacts of failure..." (DP-4-1) }\end{array}$ \\
\hline & & $\begin{array}{l}\text { "...I expect that in the future, all people here can get and up-to-date with current } \\
\text { information, are able to transform the information and become journalists for Klagen, } \\
\text { this is Klagen, this is my village, and they are proud of their village..." (DP-4-2) }\end{array}$ \\
\hline 5 & DP-5 & "...so we don't start from the top, we start from the bottom..." (DP-5-1) \\
\hline 6 & DP-6 & $\begin{array}{l}\text { "...we expect our village can be a pilot project for smart village development. If } \\
\text { Banyuwangi has its" own concept, we have different concept. I am sure that we have } \\
\text { strong commitment and wide thinking..." we just do not move in a long time." (DP-6-1) }\end{array}$ \\
\hline
\end{tabular}


The data indicate that through community dialog, Klagen community shares their expectations to develop (DP-1-1; DP-1-2; DP-2-1; DP-4-1; DP-4-2; DP-6), commitment (DP-6-1; DP5-1), motivates each other and strengthens other community elements, including youth $(D P-1-3 ; D P-4-1 ; D P-4-2)$ and other local members $(D P-3-$ $1)$, reveals need for revitalization $(D P-6-1)$, senses pride and glory of their village ( $D P$ 4-2), expresses readiness to cooperate (DP-1-3; DP-6-1) and identifies some issues to be solved together (DP-2-1). Lack of community consciousness, knowledge and skills are major barriers constraining local community to participate in development planning and process (Razzaq et al., 2013).

Through community dialog, Klagen community also reveals their needs and passions to develop several areas, including education, tourism, agriculture, family enterprises, rural communication and information systems. They are engaging in collaborative thinking and analysis to define problems, what make them difficult to grow. The community dialog strengthens their intra-group sense and inter-relationship as they express common and shared goals. This indicates that community dialog can prospectively form social capital which is the resource and asset for rural development. Social capital promotes individual and collective action formed through relationship, network, mutuality, trust and social norm in development (Park et al., 2012; Surjono et al., 2015). Willingness to cooperate shown by Klagen community can impact on conflict mitigation and risk reduction (Leenstra, 2018; Park et al., 2012). Community capacity to define and solve issues are highly valued and needed in rural development, especially when the community faces "disequlibria" (Bollman, 2000, p. 5). Moreover, rural sustainability is determined by its' local people capacity, including values, attitudes and institutions, to respond and adjust to external environment (Li et al., 2019, p. 140).

Through community dialog, the local people also voices and disseminates their passion to initiate development (voiced by $D P-5-1$ ). They are starting development from the ground, instead of waiting for top-bottom development plan. Farmers' initiative is more likely generating intrinsic motivation and widespreading local enthusiasm to develop and socially change (Ye, 2002, p. 1, cited in van der Ploeg et al., 2015 , p. 25). The data also show that community dialog strengthens their togetherness (as displayed in DP-6-1). This indicates that community dialog increases community awareness to align their individuality into social-collective dimension (Landini et al., 2014).

Klagen community's positive psychological state, character, attitude towards development and constructive shared emotion contagion are key determinants for rural development. Their collective character, shared positive emotion, commitment, expectation and identity pride can result in positive intra-community connection, confidence, mutual trust and craftsmanship to promote their own development. Humancommunity factor is one of basic elements in development. It is human capital of development, a determinant of successful development (Aref \& Gill, 2009; Bombiak \& Marcysiak, 2017; Szymańska \& Chodkowska-Miszczuk, 2011; Wu, 2015). Building physical infrastructure to develop rural only is not adequate, since it requires the integration of material, immaterial of local community attitude, norms, culture, values, institutions and external environment (Li et al., 2019). 


\subsection{Local Knowledge Generation, Collective Learning and New Knowledge Dissemination}

The study finds that community dialog enables indigenous knowledge sharing, collective learning process and knowledge transfer. This is as evidenced by following sample of data excerpts.

Table 3. Knowledge and Shared learning

\begin{tabular}{|c|c|c|}
\hline No. & $\begin{array}{c}\text { Dialog } \\
\text { Participant }\end{array}$ & Data extract \\
\hline \multirow[t]{5}{*}{1.} & \multirow[t]{5}{*}{ DP-2 } & $\begin{array}{l}\text { "...in Panggungharjo. Its' community has high mobility because it is close to } \\
\text { urban area. Its' current potential resource is culinary. The income from culinary is } \\
\text { above target. The culinary can contribute to their economic income in } 6 \text { months, } \\
\text { even though the target is } 1 \text { year. Its' popular culinary is using joglo concept. They } \\
\text { use Mataraman concept, the past style. So, } 1 \text { package for } 1 \text { family. This family will } \\
\text { prepare their own food, they cook by themselves. The waitress will only } \\
\text { guide.... So, in general, they come, they cook by themselves, eat and pay...(DP-2- } \\
\text { 1) }\end{array}$ \\
\hline & & $\begin{array}{l}\text { "...and about waste management. They have oil production. I forget the name. It is } \\
\text { marketable..." (DP-2-2) }\end{array}$ \\
\hline & & $\begin{array}{l}\text { "... and home industries are centralized in one location and trained. They also } \\
\text { welcome other people to visit. They show their village product }(U M K M) \text { product. } \\
\text { There are many visits. When I come there to observe, there are also some people } \\
\text { from Sumatra come..." (DP-2-3) }\end{array}$ \\
\hline & & $\begin{array}{l}\text { "...they also allow us to come and learn...it's free of charge, but we have to find } \\
\text { our own accommodation..." (DP-2-4) }\end{array}$ \\
\hline & & $\begin{array}{l}\text { "...we also want to reduce bank titil. There is bank titil, not because the people } \\
\text { needs it, but because of hobby. Even, they inherit debt to their children..." (DP-2- } \\
\text { 5) }\end{array}$ \\
\hline \multirow[t]{5}{*}{2} & \multirow[t]{5}{*}{ DP-1 } & $\begin{array}{l}\text { "...one more things is because they don't have any other activities. They have } \\
\text { many spare time... and because of their mindset. Their mindset is still } \\
\text { unopen.....they do it through back ways..." (DP-1-1) }\end{array}$ \\
\hline & & $\begin{array}{l}\text { "...if we see outside there, outside Nganjuk, we also want to develop the same } \\
\text { thing. But I am also aware that we have different social and economical } \\
\text { backgrounds. The majority of our population are farmers. So...the financial } \\
\text { circulation is not really supporting..." (DP-1-2) }\end{array}$ \\
\hline & & $\begin{array}{l}\text { "the majority of our population works as farmers. Some of them do not work on } \\
\text { their own land. They are paid. There are also bawang merah farmers. But the } \\
\text { barrier is on the marketing. Sometimes, they want to process their farm products } \\
\text { into other products...but they don't know how to market it..." (DP-1-3) }\end{array}$ \\
\hline & & $\begin{array}{l}\text { "... and there is an area..we call it Dusun Kidul. Dusun Kidul is a barren area, but } \\
\text { we try to plant it gradually. The people here helps by providing jeruk bali plant, } \\
\text { from Mas Wiwit. We try to centralize its' planting there..." (DP-1-4) }\end{array}$ \\
\hline & & $\begin{array}{l}\text { "maybe we have... we have some short trees to plant, so that the roadside view will } \\
\text { be more beautiful. If we plant big trees, such as waru, trembesi, it is too big and } \\
\text { will block road...maybe if we arrange the plants, along the road sides, at the right } \\
\text { and left of the roads, or we plant flowers..." (DP-1-5) }\end{array}$ \\
\hline 3 & DP-4 & $\begin{array}{l}\text { "...we call it nyadran or cleaning village. It is a unique thing, which other villages } \\
\text { don't have it. So...maybe when there is nyadran, we can inform the event to other } \\
\text { people, to attract tourists, even though it is still local tourists. It will attract others } \\
\text { to come and we also can sell... here, we start the ceremony by having slametan in } \\
\text { burial ground, after slaughtering buffaloes, we have tahlilan together to express } \\
\text { our thankful to God" (DP-4-1). }\end{array}$ \\
\hline
\end{tabular}


The study shows that through community dialog, diverse indigenous knowledge are generated, collected and shared. Several local knowledge are revealed, inter-connected with other participants' knowledge, added, reinforced and confirmed by other members. The data show that the local people know current changes around them $(D P-2-1 ; D P-2-2 ; D P-2-3)$, uniqueness of their village $(D P-1-2)$, human-related issues $(D P-2-5 ; D P-1-1)$, environmental issues and conditions (DP-1-4; DP-1-5), economic issues (DP-2-5), and cultural uniqueness $(D P-4-1)$. Various aspects of Klagen community local understanding is developed through their day-by-day interaction with their environment, other people and the neighboring village community (Aswani et al., 2018; Dawoe et al., 2012; UNESCO, 2017), embedded in practices, institutions, relationships and rituals (BRACED, 2018; World Bank, 1998). Local people tend to have detailed knowledge on their local environment, agriculture which can be resources for increasing their productivity (Dawoe et al., 2012; Taylor \& de Loë, 2012, p. 1214).

Community dialog is also a place for disseminating new knowledge. DP-2 shares his new learning after visiting Desa Panggungharjo. He learns how Panggungharjo develops its' culinary tourism, water management system and home industries centre (as evidenced in DP-2$3)$. He disseminates his new findings to allow other participants understand and elaborate the new knowledge and adapt it with their own village environment, demographical and economical circumstances. This indicates that through community dialog, knowledge sharing and exchange occur. Moreover, the newly gained knowledge sharing can potentially promote innovative knowledge, performance (Roper et al., 2017) and combined knowledge through co-production of knowledge (BRACED, 2018, p. 4). Through community dialog, the dialog participants are expanding their knowledge as a responsive act towards changing environment. Local knowledge tends to be dynamic, expanding and renewing (UNESCO, 2017, p. 22).

The study confirms that the elicitation of local knowledge, combination of local and academic knowledge and transfer of new knowledge during the dialog is the basis for development. This is verified by existing studies by confirming the vital roles of local knowledge contribution to development and its' sustainability. Local knowledge provides information for community-based assessment development program (UNESCO, 2017), contributes to planning process, especially for technical information and technical investigation (Taylor \& de Loë, 2012, p. 1213), increases community resilience and development sustainability (Ŝumane et al., 2018, p. 239), provides basis for development (Fritz-Vietta et al., 2017; Smith, 2011; World Bank, 1998), informs development programs (Aswani et al., 2018; Kolawole, 2001), generates problem solving thinking (World Bank, 1998), increases community resilience and adaptation to changing environment and uncertainty (Beckford \& Barker, 2007; García et al., n.d.; Setten \& Lein, 2019; UNESCO, 2017), enhances ecological understanding (Bala, 2015), development resources (Warren \& Rajasekaran, 1993), informs decision making (BRACED, 2018; García et al., n.d.; Kolawole, 2001), disaster mitigation and life-risk protection (Ngwes et al., 2018; Sultana et al., 2018).

The community dialog also facilitates the contagion of learning motivation. An individual who is actively exploring his surrounding and learning from village model is not only transferring new knowledge, but also inviting other people to observe and learn together (DP24). The local knowledge pronounced by the Klagen indigenous community is also combined with the practical and academic knowledge of the external developing team (higher education institution). Thus, there is a shared learning between the local community participants and external developing agents through joint-knowledge. Local knowledge only is likely inadequate to boost development performance, joint knowledge between local and academic/external/ scientific knowledge is needed (Bodorko's \& Pataki, 2009; BRACED, 2018; Kolawole, 2001; Sūmane et al., 2018; Taylor \& de Loë, 2012; Un \& Rodríguez, 2018). 


\subsection{Development Vision and Plan}

The findings show that community dialog is a means for the participants to voice their individual vision for their village development. The following table represents categories of individuals' vision informing the potential development programs.

Table 4. Individual Development vision and plan towards shared vision

\begin{tabular}{|c|c|c|}
\hline $\begin{array}{c}\text { Dialog } \\
\text { Participant }\end{array}$ & $\begin{array}{c}\text { Development } \\
\text { Vision }\end{array}$ & $\begin{array}{l}\text { Development } \\
\text { Sector }\end{array}$ \\
\hline \multirow[t]{5}{*}{ DP-1 } & Online administration (DP-1-1-1) & Public service development (DP-1-2-1) \\
\hline & Improving public services (DP-1-1-2) & Public service development (DP-1-2-2) \\
\hline & $\begin{array}{l}\text { Education, community training (DP-1- } \\
1-3 \text { ) }\end{array}$ & $\begin{array}{l}\text { Education-human resource development (DP- } \\
1-2-3 \text { ) }\end{array}$ \\
\hline & Administration training (DP-1-1-4) & Public service development (DP-1-2-4) \\
\hline & Information transparency (DP-1-1-5) & Public service development (DP-1-5-2) \\
\hline \multirow[t]{3}{*}{ DP-2 } & $\begin{array}{l}\text { Increasing agriculture productivity } \\
\text { (DP-2-1-1) }\end{array}$ & $\begin{array}{l}\text { Agricultural-economic development (DP-1-2- } \\
\text { 1) }\end{array}$ \\
\hline & Marketing training (DP-2-1-2) & Economic development (DP-1-2-2) \\
\hline & Loan centre (DP-2-1-3) & Economic development (DP-1-2-3) \\
\hline DP-3 & Reviving Nyadran culture (DP-3-1-1) & Cultural-social development (DP-3-2-1) \\
\hline \multirow[t]{3}{*}{ DP-4 } & Youth journalists (DP-4-1-1) & Human resource development (DP-4-2-1) \\
\hline & $\begin{array}{l}\text { ICT training (web, video, photoshop) } \\
\text { (DP-4-1-2) }\end{array}$ & $\begin{array}{ll}\begin{array}{l}\text { Education-human } \\
\text { development (DP-4-2-2) }\end{array} & \text { resource-technology } \\
\end{array}$ \\
\hline & Information access (DP-4-1-3) & $\begin{array}{l}\text { Information and technology development } \\
\text { (DP-4-2-3) }\end{array}$ \\
\hline \multirow[t]{4}{*}{ DP-5 } & Business training (DP-5-1-1) & Economic development (DP-5-2-1) \\
\hline & Base camp for activity (DP-5-1-2) & Human resource development (DP-5-2-2) \\
\hline & $\begin{array}{l}\text { Enhancing youth sport activities (DP- } \\
5-1-3 \text { ) }\end{array}$ & $\begin{array}{l}\text { Youth-human resource development (DP-5-2- } \\
\text { 3) }\end{array}$ \\
\hline & Printing business (DP-5-1-4) & Economic development (DP-5-2-4) \\
\hline \multirow[t]{3}{*}{ DP-6 } & $\begin{array}{l}\text { Trees planting along the side-roads } \\
\text { (DP-6-1-1) }\end{array}$ & Environmental development (DP-6-2-1) \\
\hline & Installing wi-fi connection (DP-6-1-2) & $\begin{array}{l}\text { Information and technology development } \\
\text { (DP-6-2-2) }\end{array}$ \\
\hline & Proposal writing training (DP-6-1-3) & $\begin{array}{l}\text { Education-human resource development (DP- } \\
6-2-3 \text { ) }\end{array}$ \\
\hline
\end{tabular}

DP=Dialog Participant

The study shows that through community dialog, the community expresses development initiatives. Each member articulates his individual's development vision, ranging from economic, human resource/education, information-technology, public service, cultural-social and environment development. During the dialog, they articulate significant issues which should be solved. Some participants share identical development sector: education-human resource development (DP-1-2-3; $D P-4-2-1 ; D P-4-2-2 ; D P-5-2-2 ; \quad D P-5-2-3 ; \quad D P-6-2-3)$, economic development (DP-1-2-1; $\quad D P-1-2-2 ; \quad D P-1-2-3 ; \quad D P-5-2-1 ; \quad D P-5-2-4)$ and information-technology development (DP-4-2-3; $D P-6-2-2)$. The study also proves that through community dialog, Klagen community articulates shared vision towards the elements of a smart village. A smart village is different from ordinary village as it is implementing integration of smart technology, resource and institution toward self-reliance and sustainability (ETR 90, smart village, energy \& wetlands research group, CES, IISc, 2015, cited in Subekti \& Damayanti, 2019, p. 20). The community dialog enables the articulations of individuals' vision, revealed rural constraints and information for building shared vision. This shared vision is necessary for the direction of development acts. This shared vision is also an input material for 
framing a development plan. Thus, community dialog encourages shared development vision building and planning. Development vision plays significant contribution since vision projects organization's future orientation, long term and comprehensive view (Braun et al., 2012; Preller et al., 2018). Shared vision is stimulated from thinking based on knowledge and experience (Papulova, 2014). It plays multi-functions, such as provides a road map (Preller et al., 2018), defines and enables people to follow focused opportunity (Preller et al., 2018), envisions experience, product understanding and goals (Conroy \& Berke, 2004; Kollmann et al., 2009), provokes commitment and professionalism (Martin et al., 2014), generates a driving force (Martin et al., 2014), presents strategic challenges and sets priority sectors (Asian Development Bank, 2006), informs strategies (Fuldauer et al., 2019), contributes some element of strategic management and strategy formulation (Corrall, 2009; Papulova, 2014; Revilla \& Rodríguez, 2011), provides guidance and orientation (Papulova, 2014; United Nations, n.d.).

The cooperation between Klagen local community and external developing partners indicates that shared vision requires joint-knowledge, the integration between local and scientific knowledge. Vision building needs joint-learning (Lavergne \& Saxby, 2001) and analysis of constraints, past experiences, strategic framework and investment (African Development Bank, 2000). Participatory discussion is needed in shared development vision and drafted vision (Dlouhá \& Pospíšilová, 2018).

Besides facilitating vision articulation, community dialog informs development planning. At the end of the dialog, the local community and external agents/actors agree to start smart village development by executing business training for youth and women empowerment. Training on how to produce krupuk bawang will be provided to empower Klagen's women. This initiative action is relevant to community vision on economic-agricultural and education-human resource development. Development plan is vital for rural development as it provides development pathway (Battaglia et al., 2019; Leekwa-Teemane Local Municipality, 2014), need identification to achieve goals (Shapiro, n.d.), weakness analysis (Mikovits et al., 2018), new environment challenge response (Chimhowu et al., 2019), clear ways to achieve goals (Government of the Sultanate of Oman, 2016; Shapiro, n.d.), preparation process and decision making guidance (Bakır et al., 2018; Filho et al., 2019), development areas prioritization (Mouzughi et al., 2014), tools, techniques, ways to develop determinant strategy (SMS Research \& Marketing Services, Inc., 2010), coordinated efforts guidance (Apanavičienè \& Šalnienè, 2010; Pea, n.d.) and assurance (Conroy \& Berke, 2004).

\subsection{Rural Development Networking}

Community dialogue allows the local community to exercise their capacities in building social relationship locally and externally. The success of rural development is determined by collective actions of communities and networks, rather than individual capacities (Dobay, 2011). Klagen networking capacity is vital for expanding their knowledge, innovation and sustain long-term development process. This is as evidenced by the following data.

\begin{tabular}{ll}
\hline $\begin{array}{l}\text { Dialog } \\
\text { Participant }\end{array}$ & \multicolumn{1}{c}{$\begin{array}{c}\text { Development } \\
\text { Vision }\end{array}$} \\
\hline EA & "...our position here is Klagen's partners. We expect we can invite experts to provide relevant, \\
& needed training. After our visit, we try to re-design. We think that training is just a gate for next \\
activities, may be youth training, for building a smart village. I think we are going to use the result \\
of our discussion today as materials for proposing program. We are going to do it step by step and \\
we should prioritize which action should be taken initially." (EA-1) \\
"...for instance, a simple example, may be pak Kades knows about this. There is a village, Desa \\
\\
$\begin{array}{l}\text { Jambu, in which the head of the village is successful in building a smart village. They are starting } \\
\text { with planting kelengkeng. It becomes their icon. Then they develop various things, including } \\
\text { centre of Kambing Etawa. They are now becoming a smart village..." (EA-2) }\end{array}$ \\
"....so what pak Kades designs as nawa cita is reflection of smart village...I mean it covers village
\end{tabular}




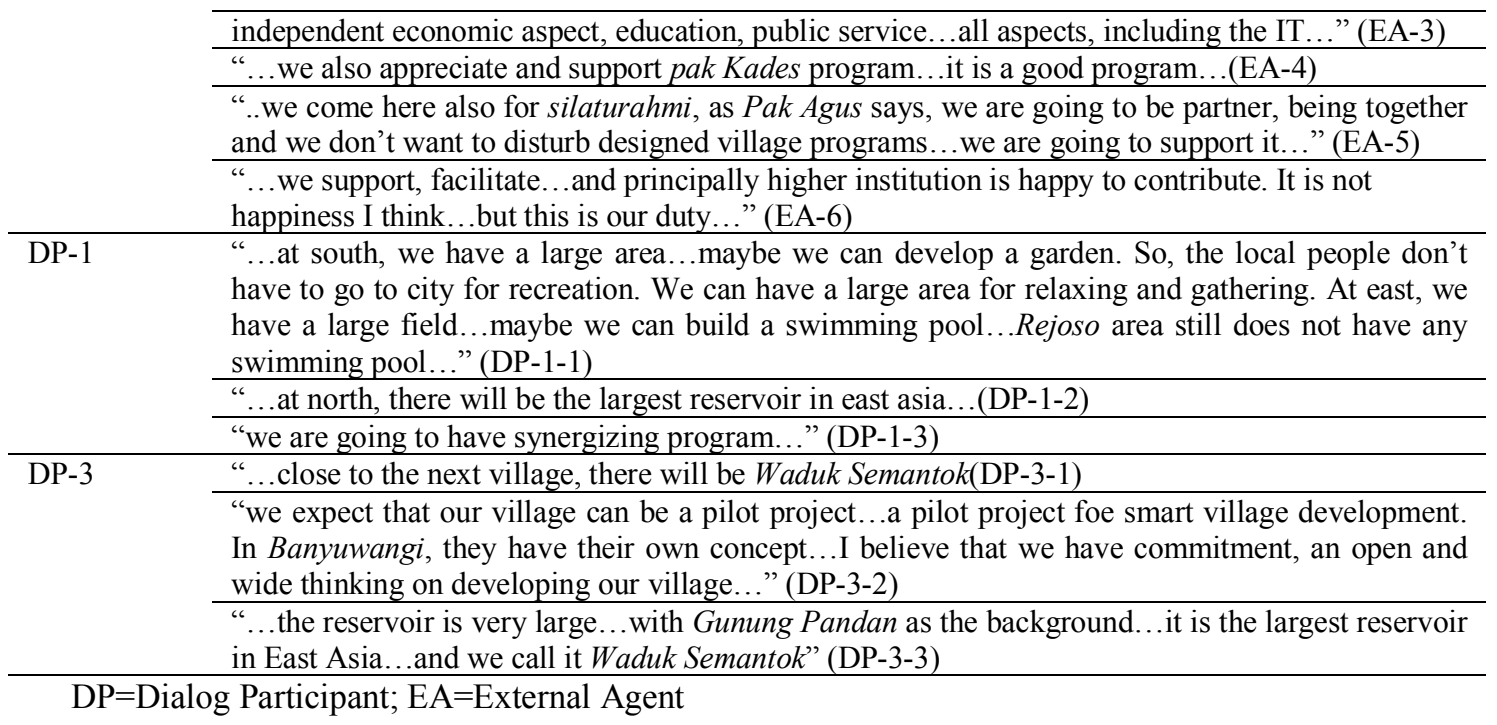

The study indicates that community dialog strengthens social relationship between other local people and external agents. It is resulted in agreements on the roles of both sides of the parties (EA-1;EA-4; EA-4;EA-5;EA-6; DP-1-3), synergizing programs, knowledge and actions $(D P-1-3 ; D P-1-1)$ and joint-response for facing future regional development changes $(D P-1-2$; $D P-1-2$; DP-3-2; DP-3-3). The potential development of Waduk Semantok stimulates Klagen community motivation to prepare themselves and adapts to prospective changes. Frequently, pressure to change is critical points forcing rural areas to change (Rivera \& Qamar, 2003, p. 5). The dialog participants also demonstrate mutual understanding, support, appreciation and trust, which are the foundation of development. Rural development requires cooperation among different stakeholders (Ministry of Regional Development, 2013), social coordination, empowerment plan, mutual consultation and negotiation (Derkzen, 2008; IFAD, 2015), trust (impacted in bonding, bridging and linking) and reciprocity (Abbott \& Fuller-Love, 2020; Kelliher et al., 2018). To develop, farmers should establish social relationship internally and externally: with industrial organization, surrounding people, educational institution and local authorities (Rustinsyah, 2019, p. 6). Rural networks should not only be limited to bordered geographical areas (Onitsuka \& Hoshino, 2018). Holistic networks are created through collaboration of internal networks: project teams and community engagement and external networks, including external agency and peer to peer interaction (Morrison \& Ramsey, 2019).

The community dialog also inspires local community to think on what they can expand to face Waduk Semantok development and how to increase their skills and competencies to be able to survive and enhance their livelihood (economy) after Waduk Semantok is built. This indicates that Klagen community feels the needs to expand their agricultural capacities and diversified economy and moves from traditional agricultural sector to more innovated ways of living (Douthwaite et al., 2006). This expansion process can be encouraged by joint knowledge and innovation created through networking. Rural networking facilitates agricultural knowledge extension (Rivera \& Qamar, 2003), limited knowledge handling and diversified rural skills (Morrison \& Ramsey, 2019), innovation (Douthwaite et al., 2006; Esparcia, 2014; Richter, 2019) which is consisting of knowledge innovation and innovation transfer (Dimitar et al., 2014), diversification impacted on economic improvement (Johny et al., 2017), group work character building, including trust, cooperation, knowledge and problem sharing, values respect, shared rules functioning and shared objective attainment (Landini et al., 2017) and networking competences (building effective, efficient, accountability and democratic interactions) (Bebbington \& Kopp, 2012), the increasing employment, availability of natural resources (Rustinsyah, 2019), cooperation to face current situation (Jesus \& Franco, 2016; Lee et al., 
2005), bond and social connectivity (Tiwari et al., 2019), competitive advantage addition (Abbott \& Fuller-Love, 2020), rural community resilience (Li et al., 2019; van Aswegen \& Retief, 2020), changing environment adaptation (Chaudhury et al., 2017), rural development program evaluation (ENRD, 2016). Moreover, community dialog increases rural partners' understanding on needs and characters of the targeted developed rural areas (Lucatelli \& De Matteis, 2013).

This study presents the promises of community dialog conducted before the process of designing a rural village development program. Community dialog offers a wide range of advantages which can catalyze development program planning and process. The following figure encapsulates the findings and discussion of the study.

The model of potentials of community dialog for smart village development at initialstage shows several benefits of conducting local community dialog as the ground for developing community development program. It shows that community dialog can strengthen community commitment and awareness to develop. Through community dialog, the development actors can think and analyze collaboratively, share voices, develop relationship and mutuality, trust, mitigate conflict, strengthen commitment, motivation, enthusiasm, individual-social alignment and share goals. Community dialog generates knowledge sharing, local knowledge generation and group learning. This constitutes local knowledge identification, combined local-scientific knowledge, knowledge expansion, community-based assessment program, development process plan, development program information, problem solving, community resilience and adaptation, increasing development resource, disaster mitigation, life-risk protection, learning motivation contagion. Community dialog grounds development vision and plan. It informs vision building, future orientation, comprehensive view, road map, focused opportunity, driving force, prioritizing sectors, strategic planning, guidance, development plan, weakness analysis, tools, technique for development, assurance and coordinated efforts. Community dialog broadens rural networks. It expands social relationship, mutual understanding, consultation, negotiation, trust, reciprocity, collaboration, knowledge extension and transfer, innovation, diversification, problem sharing, bonding and connectivity, adaptation, competitive advantage and program evaluation.

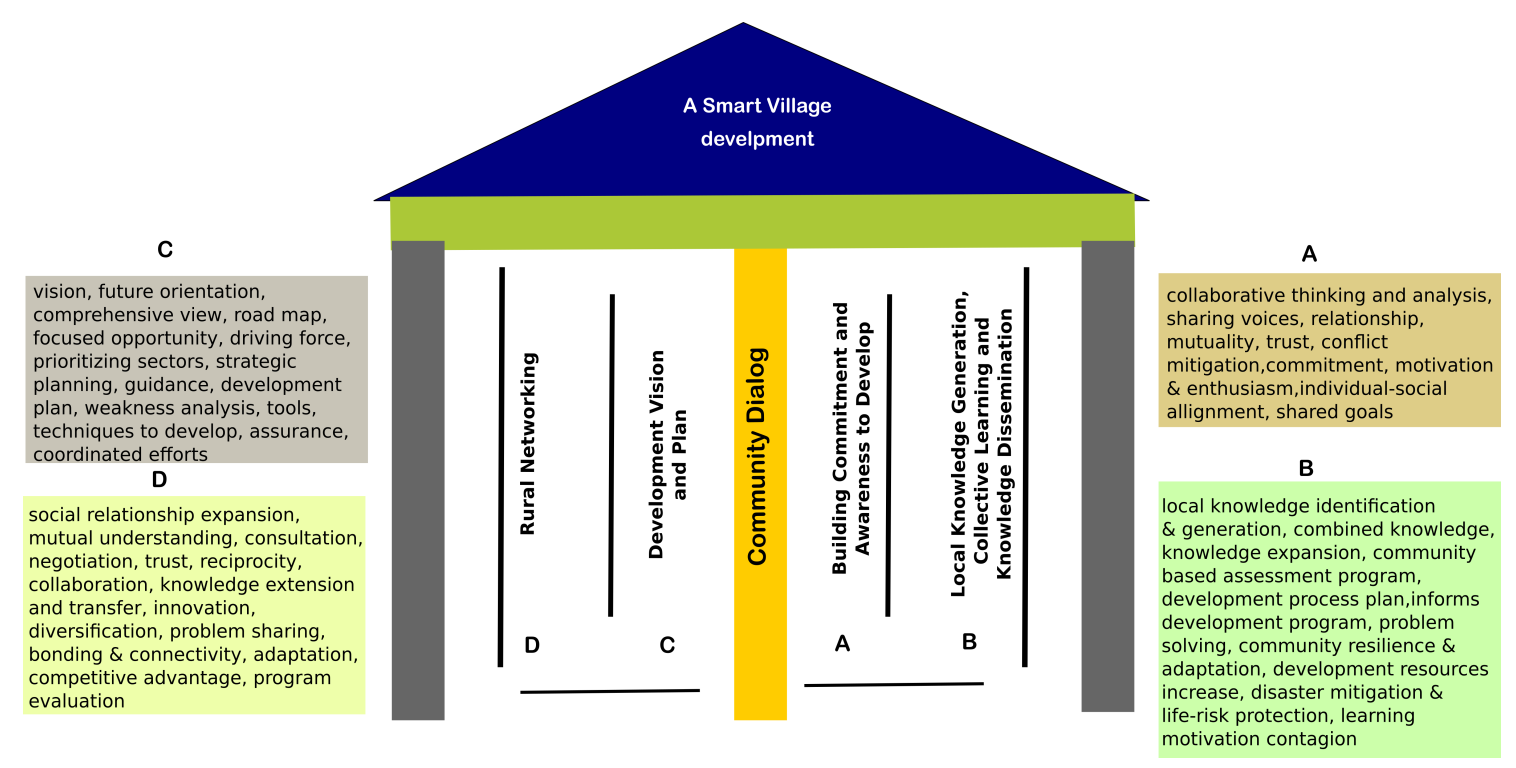

Figure 2. Model of potentials of community dialog for smart village development at initial stage 


\section{Conclusion}

Rural development should be based on rural needs and characters. These needs and rural characters can be analyzed through community dialog between local community and external agents. Effective dialog provides the basis for rural sustainable development. This study examines four promises of community dialog for laying development ground. The first promise of community dialog is building and strengthening development actors' commitment and awareness. Community dialog enables collaborative thinking and analysis, voices sharing, relationship, network, mutuality and trust bonding, conflict mitigation, increasing commitment, motivation and enthusiasm, individual-social alignment and shared goals. The second benefit is local knowledge generation, collective learning and knowledge dissemination. Community dialog triggers collective learning and sharing. Furthermore, it promotes local knowledge articulation and generation of collection, combined local-scientific knowledge, knowledge expansion, community based assessment program, development process plan, problem solving, community resilience and adaptation, increasing number of development resources, disaster mitigation and life-risk protection and learning motivation contagion. The third promise is shared development vision and plan. Community dialog is a place for each individual discusses, negotiates, shares and agrees the shared vision which is the basis for development plan. Community dialog provides future orientation, comprehensive view, road map, focused opportunity, driving force, priority sectors, strategic planning, guidance, development plan, weakness analysis, development tools and techniques, assurance and framework for coordinated efforts. The fourth promise is rural networking. Community dialog enables rural community to expand their social relationship. Rural networking implicates on mutual understanding, consultation and negotiation, trust, reciprocity, collaboration, knowledge extension and transfer, innovation, diversification, problem sharing, bonding and connectivity, adaptation, competitive advantage and program evaluation.

\section{References}

Abbott, J., \& Fuller-Love, N. (2020). Networking for equine complementary therapists in the rural economy. Journal of Rural Studies. https://doi.org/10.1016/j.jrurstud.2020.01.011

African Development Bank. (2000). Agriculture and rural development sector. Bank group policy (pp. 1-52). African Development Bank.

Aguila, G. M., \& Ragot, R. (2014). Ecotourism Industry in Ilijan Batangas City, Philippines: Assessing Its Effects as a Basis of Proposed Tourism Development Plan. Quarterly Journal of Business Studies, 1(1), 24-35.

Anderson, A., Loomba, P., Orajaka, I., Numfor, J., Saha, S., Janko, S., Johnson, N., Podmore, R., \& Larsen, R. (2017). Empowering Smart Communities. Electrification, education, and sustainable entrepreneurship in iEEESmart Village initiatives. IEEE Electrification Magazine, 6-16.

Anetzberger, G. J., Ishler, K. J., Mostade, J., \& Blair, M. (2004). Gray and gay: A community dialogue on the issues and concerns of older gays and lesbians. Journal of Gay \& Lesbian Social Services, 17(1), 23-45.

Anríquez, G., \& Stamoulis, K. (2007). Rural Development and Poverty Reduction: Is Agriculture Still the Key? (pp. 1-39) [ESA Working Paper No. 07-02]. Agricultural Development Economics Division The Food and Agriculture Organization of the United Nations. www.fao.org/es/esa

Apanavičienè, R., \& Šalnienè, E. (2010). Strategic planning of construction investment projects in the content of regional development. Modern Building Materials, Structures and Techniques. The 10th International Conference, Vilnius, Lithuania. http://www.vgtu.lt/en/editions/proceedings

Aref, F., \& Gill, S. S. (2009). Rural Tourism Development through Rural Cooperatives. Nature and Science, 7(10), 68-73. 
Ashley, C., \& Maxwell, S. (2001). Rethinking rural development. Development Policy Review, 19(4), 395-425.

Asian Development Bank. (2006). Indonesia. Strategic Vision for Agriculture and Rural Development (Publication Stock No: 030807; pp. 1-167). Asian Development Bank.

Aswani, S., Lemahieu, A., \& Sauer, W. H. H. (2018). Global trends of local ecological knowledge and future implications. PLos ONE, 13(4), 1-19. https://doi.org/10.1371/journal. pone.0195440

Atchoarena, D., \& Gasperini, L. (2003). Education for rural development: towards new policy responses (pp. 9-406). Food and Agriculture Organization of the United Nations \& United Nations Educational, Scientific and Cultural Organization. http://www.unesco.org/iie

Bakır, N. Y., Doğan, U., Güngör, M. K., \& Bostanc1, B. (2018). Planned development versus unplanned change: The effects on urban planning in Turkey. Land Use Policy, 77, 310321. https://doi.org/10.1016/j.landusepol.2018.05.036

Bala, P. A. (2015). The potential role of local knowledge in community forest management: The case of Kidundakiyave Miombo Woodland, Tanzania [Thesis].

Barrow, W. (2010). Dialogic, participation and the potential for Philosophy for Children. Thinking Skills and Creativity, 5, 61-69. https://doi.org/doi:10.1016/j.tsc.2010.01.002

Battaglia, M., Annesi, N., Pierantoni, I., \& Sargolini, M. (2019). Future perspectives of sustainable development: An innovative planning approach to inner areas. Experience of an Italian alpine region. Futures, 114(102468), 1-15. https://doi.org/10.1016/j.futures.2019.102468

Bayes, A. (2001). Infrastructure and rural development: insights from a Grameen Bank village phone initiative in Bangladesh. Agricultural Economics, 25, 261-272.

Bebbington, A., \& Kopp, A. (2012). Networking and rural development through sustainable forest management: frameworks for pluralistic approaches. FAO.

Beck, B., Newton, G., \& Maurana, C. A. (2002). Lessons in Community Building: From Dialogue to Action. Journal of Higher Education Outreach and Engagement, 7(3), 2739.

Beckford, C., \& Barker, D. (2007). The role and value of local knowledge in Jamaican agriculture: adaptation and change in small-scale farming. The Geographical Journal, 173(2), 118-128.

Bodorko's, B., \& Pataki, G. (2009). Linking academic and local knowledge: community-based research and service learning for sustainable rural development in Hungary. Journal of Cleaner Production, 17, 1123-1131. https://doi.org/doi:10.1016/j.jclepro.2009.02.023

Bollman, R. D. (2000). Human capital and rural development: What are the linkages? (Working Paper \#39 Catalogue no. 21-601-MIE99039; pp. 1-30). Minister of Industry, Statistics Canada.

Bombiak, E., \& Marcysiak, A. (2017). Rural human capital as a determinant of economic development. Proceedings of the 8 Th International Scientific Conference Rural Development 2017. 8th International Scientific Conference Rural Development 2017. Bioeconomy Challenges, Aleksandras Stulginskis University. https://doi.org/10.15544/RD.2017.133

Bonham, V. L., Citrin, T., Modell, S. M., Franklin, T. H., Bleicher, E. W. B., \& Fleck, L. M. (2009). Community-Based Dialogue: Engaging Communities of Color in the United States' Genetics Policy Conversation. J Health Polit Policy Law, 34(3), 325-359. https://doi.org/doi:10.1215/03616878-2009-009

BRACED. (2018). Interactions between local and scientific knowledge systems for weather and climate services (pp. 1-9) [Learning paper\#9]. 
Braun, S., Wesche, J. S., Frey, D., Weisweiler, S., \& Peus, C. (2012). Effectiveness of mission statements in organizations - A review. Journal of Management \& Organization, $18(4), 430-444$.

Bruckmeier, K., \& Tovey, H. (20008). Knowledge in Sustainable Rural Development: From Forms of Knowledge to Knowledge Processes. Sociologia Ruralis, 48(3), 313-329. https://doi.org/DOI: 10.1111/j.1467-9523.2008.00466.x

Cabraal, R. A., Barnes, D. F., \& Agarwal, S. G. (2005). Productive uses of energy for rural development. Annu. Rev. Environ. Resour, 30, 117-44. https://doi.org/doi: 10.1146/annurev.energy.30.050504.144228

Capizzo, L. (2018). Reimagining dialogue in public relations: Bakhtin and open dialogue in the public sphere. Public Relations Review, 44, 523-532. https://doi.org/10.1016/j.pubrev.2018.07.007

Chaudhury, A. S., Thornton, T. F., Helfgott, A., Ventresca, M. J., \& Sova, C. (2017). Ties that bind: Local networks, communities and adaptive capacity in rural Ghana. Journal of Rural Studies, 53, 214-228. http://dx.doi.org/10.1016/j.jrurstud.2017.05.010

Chen, Y.-R. R., Hung-Baesecke, C.-J. F., \& Chen, X. (n.d.). Moving forward the dialogic theory of public relations: Concepts, methods and applications of organization-public dialogue. Public Relations Review. https://doi.org/10.1016/j.pubrev.2019.101878

Chimhowu, A. O., Hulme, D., \& Munro, L. T. (2019). The 'New' national development planning and global development goals: Processes and partnerships. World Development, 120, 76-89. https://doi.org/10.1016/j.worlddev.2019.03.013

Conroy, M. M., \& Berke, P. R. (2004). What makes a good sustainable development plan? An analysis of factors that influence principles of sustainable development. Environment and Planning, 36, $1381^{\wedge} 1396$. https://doi.org/DOI:10.1068/a367

Corrall, S. (2009). Strategic Development. In Handbook of Library Training Practice and deveLopment (pp. 213-260).

Coyle, F. J. (2016). 'Best practice' community dialogue: The promise of a small-scale deliberative engagement around the siting of a carbon dioxide capture and storage (CCS) facility. International Journal of Greenhouse Gas Control, 45, 233-244. http://dx.doi.org/10.1016/j.ijggc.2015.12.006

Dawoe, E. K., Quashie-Sam, J., Isaac, M. E., \& Oppong, S. K. (2012). Exploring farmers' local knowledge and perceptions of soil fertility and management in the Ashanti Region of Ghana. Geoderma, 179-180, 96-103. https://doi.org/doi:10.1016/j.geoderma.2012.02.015

Derkzen, P. (2008). The politics of rural governance Case studies of rural partnerships in the Netherlands and Wales [Ph.D. Thesis].

DeTurk, S. (2006). The Power of Dialogue: Consequences of Intergroup Dialogue and their Implications for Agency and Alliance Building. Communication Quarterly, 54(1), 3351. https://doi.org/DOI: 10.1080/01463370500270355

Dimitar, D., Svetla, D., Ekaterina, A., \& Ivanka, S. (2014). Sustainable rural development by networking in organic agriculture and niche tourism. 89-108.

Dlouhá, J., \& Pospíśilová, M. (2018). Education for Sustainable Development Goals in public debate: The importance of participatory research in reflecting and supporting the consultation process in developing a vision for Czech education. Journal of Cleaner Production, 172, 4314-4327. http://dx.doi.org/10.1016/j.jclepro.2017.06.145

Dobay, K. M. (2011). The role of knowledge-based networks in the sustainable development of the rural space. Agricultural Economics and Rural Development, VIII(2), 213-220.

Douthwaite, B., Carvajal, A., Alvarez, S., Claros, E., \& Hernández, L. A. (2006). Building farmers' capacities for networking (Part I): Strengthening rural groups in Colombia through network analysis. KM4D Journal, 2(2), 4-18. 
Ellis, F., \& Biggs, S. (2001). Evolving themes in rural development. Development Policy Review, 19(4), 437-448.

ENRD. (2016). Connecting Rural Europe 2014-2020. European Network for Rural Development.

$\begin{array}{lllll}\text { eprints.umm. } & \text { (n.d.). } & \text { Bab } & \text { III } & \text { Deskripsi }\end{array}$ http://eprints.umm.ac.id/54784/45/BAB\%20III.pdf

Esparcia, J. (2014). Innovation and networks in rural areas. An analysis from European innovative projects. Journal of Rural Studies, 34, 1-14. http://dx.doi.org/10.1016/j.jrurstud.2013.12.004

Fabricus, C., Koch, E., Magome, H., \& Turner, S. (2004). Rights, Resources and Rural Development Community-based Natural Resource Management in Southern Africa. Cromwell Press Ltd. www.earthscan.co.uk

Fennell, S., Kaur, P., Jhunjhunwala, A., Narayanan, D., Loyola, C., Bedi, J., \& Singh, Y. (2018). Examining linkages between Smart Villages and Smart Cities: Learning from rural youth accessing the internet in India. Telecommunications Policy, 42, 810-823. https://doi.org/10.1016/j.telpol.2018.06.002

Figueroa, M. E., Poppe, P., Carrasco, M., Pinho, M. D., Massingue, F., Tanque, M., \& Kwizera, A. (2016). Effectiveness of Community Dialogue in Changing Gender and Sexual Norms for HIV Prevention: Evaluation of the Tchova Tchova Program in Mozambique. Journal of Health Communication, 21(2016), 554-563. https://doi.org/DOI: 10.1080/10810730.2015.1114050

Filho, W. L., Skanavis, C., Kounani, A., Brandli, L. L., Shiel, C., do Paço, A., Pace, P., Mifsud, M., Beynaghi, A., Price, E., Salvia, A. L., Will, M., \& Shula, K. (2019). The role of planning in implementing sustainable development in a higher education context. Journal of Cleaner Production, 235, 678e687. https://doi.org/10.1016/j.jclepro.2019.06.322

Filomeno, F. A. (2019). The potential of dialogues on social identity and diversity for immigrant civic integration. Evaluation and Program Planning, 77(101723). https://doi.org/10.1016/j.evalprogplan.2019.101723

Fritz-Vietta, N. V. M., Tahirindraza, H. S., \& Stoll-Kleemann, S. (2017). Local people's knowledge with regard to land use activities in southwest MadagascareConceptual insights for sustainable land management. Journal of Environmental Management, 199, 126-138. http://dx.doi.org/10.1016/j.jenvman.2017.05.034

Fuldauer, L. I., Ives, M. C., Adshead, D., Thacker, S., \& Hall, J. W. (2019). Participatory planning of the future of waste management in small island developing states to deliver on the Sustainable Development Goals. Journal of Cleaner Production, 223, 147-162. https://doi.org/10.1016/j.jclepro.2019.02.269

Gale, F. (n.d.). Direct Farm Marketing as a Rural Development Tool. Rural Development Perspectives, 12(2), 19-25.

García, G. A. G., Gutiérrez-Montes, I., Hernández Núñez, H. E., Salazar, J. C. S., \& Casanoves, F. (n.d.). Relevance of local knowledge in decision-making and rural innovation: A methodological proposal for leveraging participation of Colombian cocoa producers. Journal of Rural Studies. https://doi.org/10.1016/j.jrurstud.2020.01.012

Government of the Sultanate of Oman. (2016). Sustainable Agriculture and Rural Development Strategy towards 2040 (SARDS 2040) (pp. 1-72). Government of the Sultanate of Oman.

Holloway, D. (2014). A practical guide to dialogue (The Community Dialogue Critical Isuuses Series: Volume Two). www.communitydialogue.org

IFAD. (2015). Partnering for rural development. IFAD Governing Council. 
Jesus, C., \& Franco, M. (2016). Cooperation networks in tourism: A study of hotels and rural tourism establishments in an inland region of Portugal. Journal of Hospitality and Tourism Management, 29, 165-175. http://dx.doi.org/10.1016/j.jhtm.2016.07.005

Johnson, J. (2002). Poverty in Australia: Developing community dialogue Report of a qualitative research study (pp. 1-18) [The Understanding Poverty project]. Brotherhood of St Laurence. www.bsl.org.au

Johny, J., Wichmann, B., \& Swallow, B. M. (2017). Characterizing social networks and their effects on income diversification in rural Kerala, India. World Development, 94, 375392. http://dx.doi.org/10.1016/j.worlddev.2017.02.002

Kay, C. (2009). Development strategies and rural development: exploring synergies, eradicating poverty. The Journal of Peasant Studies, 36(1), 103-137. https://doi.org/DOI: $10.1080 / 03066150902820339$

Kelliher, F., Reinl, L., Johnson, T. G., \& Joppe, M. (2018). The role of trust in building rural tourism microfirm network engagement: A multi-case study. Tourism Management, 68, 1-12. https://doi.org/10.1016/j.tourman.2018.02.014

Kementerian Dalam Negeri Republik Indonesia-Direktorat Jenderal Bina Pemerintahan Desa. (2019). Data pokok desa/kelurahan (pp. 1-6). Kementerian Dalam Negeri Republik Indonesia-Direktorat Jenderal Bina Pemerintahan Desa. http://prodeskel.binapemdes.kemendagri.go.id/dpokok_grid_t01

Kitchen, L., \& Marsden, T. (2009a). Creating Sustainable Rural Development through Stimulating the Eco-economy: Beyond the Eco-economic Paradox? Sociologia Ruralis, 49(3), 273-294. https://doi.org/DOI: 10.1111/j.1467-9523.2009.00489.x

Kitchen, L., \& Marsden, T. (2009b). Development through Stimulating the Eco-economy: Beyond the Eco-economic Paradox? Sociologia Ruralis, 49(3), 273-294. https://doi.org/DOI: 10.1111/j.1467-9523.2009.00489.x

Kolawole, O. D. (2001). local knowledge utilization and sustainable rural development in the 21 st century. Ndigenous Knowledge AndDevelopment Monitor, 9(3), 13-15.

Kollmann, J., Sharp, H., \& Blandford, A. (2009). The importance of Identity and Vision to user experience designers on agile projects. Agile Conference. https://doi.org/DOI 10.1109/AGILE.2009.58

Landini, F. P., Long, N. E., Leeuwis, C., \& Murtagh, S. (2014). Theoretical Guidelines for a Psychology of Rural Development. Cuadernos de Desarrollo Rural, 11(74), 125-147. https://doi.org/doi:10.11144/javeriana.CRD11-74.tgpr

Landini, F., Vargas, G., Bianqui, V., Rebolé, M. I. M. y, \& Martínez, M. (2017). Contributions to group work and to the management of collective processes in extension and rural development. Journal of Rural Studies, 56, 143-155. https://doi.org/10.1016/j.jrurstud.2017.09.014

Laszlo, K. C., \& Laszlo, A. (2005). Dialogue as a Means of Collective Communication (Banathy, Bela \& Jenlink, Patrick M. (Eds.)). Kluwer Academic Publishers.

Lavergne, R., \& Saxby, J. (2001). Capacity Development: Vision and Implications (Capacity Development, pp. 1-11) [Occasional Series]. Canadian International Development Agency.

Lee, J., Árnason, A., Nightingale, A., \& Shucksmith, M. (2005). Networking: Social Capital and Identities in European Rural Development. Sociologia Ruralis, 45(4), 269-283.

Leekwa-Teemane Local Municipality. (2014). Integrated Development Plan 2014-2015 (Resolution Number: 77/2014; pp. 1-221). Leekwa-Teemane Local Municipality.

Leenstra, M. (2018). The human factor in development cooperation: An effective way to deal with unintended effects. Evaluation and Program Planning, 68, 218-224. http://dx.doi.org/10.1016/j.evalprogplan.2017.09.008 
Li, Y., Westlund, H., \& Liu, Y. (2019). Why some rural areas decline while some others not: An overview of rural evolution in the world. Journal of Rural Studies, 68, 135-143. https://doi.org/10.1016/j.jrurstud.2019.03.003

Longo, N. V. . (2013). Deliberative Pedagogy in the Community: Connecting Deliberative Dialogue, Community Engagement, and Democratic Education. Journal of Public Deliberation, 9(2), 1-18.

Lucatelli, S., \& De Matteis, P. (2013). Rural Urban Partnership for sustainable development (pp. 87-97). Ministry of Regional Development.

Mack, S., Hoffmann, D., \& Otte, J. (2005). The contribution of poultry to rural development. World's Poultry Science Journal, 61, 7-14. https://doi.org/DOI: 10.1079/WPS200436

Martin, J., McCormack, B., Fitzsimons, D., \& Spirig, R. (2014). The importance of inspiring a shared vision. International Practice Development Journal, 4(2), 1-15.

Maxwell, S., Urey, I., \& Ashley, C. (2001). Emerging issues in rural development (An Issues Paper, pp. 1-10). Overseas Development Institute. http://www.odi.or.uk/download/4817.pdf

McManus, P., Walmsley, J., Argent, N., Baum, S., Bourke, L., Martin, J., Pritchard, B., \& Sorensen, T. (2012). Rural Community and Rural Resilience: What is important to farmers in keeping their country towns alive? Journal of Rural Studies, 28, 20-29. https://doi.org/doi:10.1016/j.jrurstud.2011.09.003

Meinzen-Dick, R., Di Gregorio, M., \& McCarthy, N. (2004). Methods for studying collective action in rural development (CGIAR Systemwide Program on Collective Action and Property Rights, pp. 1-25) [Capri Working Paper No. 33]. International Food Policy Research Institute.

Mercer-Mapstone, L., Rifkin, W., Louis, W., \& Moffat, K. (2019). Power, participation, and exclusion through dialogue in the extractive industries: Who gets a seat at the table? Resources Policy, 61, 190-199. https://doi.org/10.1016/j.resourpol.2018.11.023

Mercer-Mapstone, L., Rifkin, W., Louis, W. R., \& Moffat, K. (2018). Company-community dialogue builds relationships, fairness, and trust leading to social acceptance of Australian mining developments. Journal of Cleaner Production, 184(https://doi.org/10.1016/j.jclepro.2018.02.291), 671-677.

Mikovits, C., Rauch, W., \& Kleidorfer, M. (2018). Importance of scenario analysis in urban development for urban water infrastructure planning and management. Computers, Environment and Urban Systems, 68, 9-16. http://dx.doi.org/10.1016/j.compenvurbsys.2017.09.006

Ministry of Regional Development. (2013). New Paradigm in action. on successful partnerships (pp. 1-139). Ministry of Regional Development, Warsaw.

Morrison, C., \& Ramsey, E. (2019). Power to the people: Developing networks through rural community energy schemes. Journal of Rural Studies, 70, 169-178. https://doi.org/10.1016/j.jrurstud.2018.07.006

Mouzughi, Y., Bryde, D., \& Al-Shaer, M. (2014). The Role of Real Estate in Sustainable Development in Developing Countries: The Case of the Kingdom of Bahrain. Sustainability, 6, 1709-1728. https://doi.org/doi:10.3390/su6041709

Nemes, G. (2005). Integrated rural development - The concept and its operation (IEHAS Discussion Papers, No. MT-DP - 2005/6, pp. 1-50) [Working Paper]. http://hdl.handle.net/10419/108086

Ngwes, N. M., Saito, O., Sato, A., Boafo, Y. A., \& Jasaw, G. (2018). Traditional and Local Knowledge Practices for Disaster Risk Reduction in Northern Ghana. Sustainability, 10(825), 1-17. https://doi.org/doi:10.3390/su10030825

NIRDPR. (n.d.). Mainstreaming Smart Village In Rural Development: A Framework For Analysis And Policy. 
Onitsuka, K., \& Hoshino, S. (2018). Inter-community networks of rural leaders and key people: Case study on a rural revitalization program in Kyoto Prefecture, Japan. Journal of Rural Studies, 61, 123-136. https://doi.org/10.1016/j.jrurstud.2018.04.008

Ounvichit, T., \& Yoddumnern-Attig, B. (2018). Community dialogs on the probabilities of community-based mangrove institution. Kasetsart Journal of Social Sciences, 39, 365e373. https://doi.org/10.1016/j.kjss.2018.07.001

Papulova, Z. (2014). The Significance of Vision and Mission Development for Enterprises in Slovak Republic. Journal of Economics, Business and Management, 2(1), 12-16. https://doi.org/DOI: 10.7763/JOEBM.2014.V2.90

Park, D.-B., Lee, K.-W., Choi, H.-S., \& Yoon, Y. (2012). Factors influencing social capital in rural tourism communities in South Korea. Tourism Management, 33, 1511-1520. https://doi.org/doi:10.1016/j.tourman.2012.02.005

Park, Y. E., \& Kang, M. (n.d.). When crowdsourcing in CSR leads to dialogic communication: The effects of trust and distrust. Public Relations Review. https://doi.org/10.1016/j.pubrev.2019.101867

Parker, J., \& Duignan, P. (n.d.). Dialogue Methods: A Typology of Community Dialogue Processes. Parker Duignan Ltd. http://www.strategicevaluation.info/se/documents/132pdff.html

Pašakarnis, G., \& Maliene, V. (2010). Towards sustainable rural development in Central and Eastern Europe: Applying land consolidation. Land Use Policy, 27, 545-549. https://doi.org/doi:10.1016/j.landusepol.2009.07.008

Pea, R. D. (n.d.). What Is Planning Development the Development of? 1-27.

Pearce, W. B., \& Pearce, K. A. (2000). Extending the Theory of the Coordinated Management of Meaning (CMM) Through a Community Dialogue Process. Communication Theory, 10(4), 405-423.

Phahlamohlaka, J., Dlamini, Z., Mnisi, T., Mashiane, T., \& Malinga, L. (2014). Towards a Smart Community Centre: SEIDET Digital Village (IFIP AICT 43; pp. 107-121). IFIP International Federation for Information Processing.

Preller, R., Patzelt, H., \& Breugst, N. (2018). Entrepreneurial visions in founding teams: Conceptualization, emergence, and effects on opportunity development. Journal of Business Venturing. https://doi.org/10.1016/j.jbusvent.2018.11.004

Prinsloo, G., Dobson, R., \& Mammoli, A. (2017). Smart Village Load Planning Simulations in Support of Digital Energy Management for off-grid Rural Community Microgrids. Ournal for Current Alternative Energy.

Razzaq, A. R. A., Mohamad, N. H., Kader, S. S. S. A., Mustafad, M. Z., Hadi, M. Y. A., Hamzah, A., \& Khalifah, Z. (2013). Developing Human Capital for Rural Community Tourism: Using Experiential Learning Approach. Procedia - Social and Behavioral Sciences, 93, 1835 - 1839.

Revilla, E., \& Rodríguez, B. (2011). Team vision in product development: How knowledge strategy matters. Technovation, 31, 118-127. https://doi.org/doi:10.1016/j.technovation.2010.10.007

Richards, P. (n.d.). Community Environmental Knowledge in African Rural Development. 28 36.

Richter, R. (2019). Rural social enterprises asembedded intermediaries: The innovative power of connecting rural communities with supra-regional networks. Journal of Rural Studies, 70, 179-187. https://doi.org/10.1016/j.jrurstud.2017.12.005

Ristianti, N. S. (2016). S.M.A.R.T. eco-village for hazardous coastal area in Bedono Village, Demak Regency. Procedia - Social and Behavioral Sciences, 227, 593-600. https://doi.org/doi: 10.1016/j.sbspro.2016.06.120

Rivera, W. M., \& Qamar, M. K. (2003). Agricultural extension, Rural development and food security challenge. Food and Agriculture Organization of The United Nations. 
Romney, P. (n.d.). The art of dialogue. Animating Democracy, 1-22.

Roper, S., Love, J. H., \& Bonner, K. (2017). Firms' knowledge search and local knowledge externalities in innovation performance. Research Policy, 46, 43-56. http://dx.doi.org/10.1016/j.respol.2016.10.004

Rustinsyah, R. (2019). The significance of social relations in rural development: A case study of a beef-cattle farmer group in Indonesia. Journal of Co-Operative Organization and Management, 7(100088), 1-7. https://doi.org/10.1016/j.jcom.2019.100088

Santoso, A. D., Fathin, C. A., Effendi, K. C., Novinto, A., Sumiar, H. R., Angendari, D. A. D., \& Putri, B. P. (n.d.). Desa Cerdas:Transformasi kebijakan dan pembangunan desa merespon era revolusi industri 4.0 (Seri Literasi Digital, pp. 1-109) [Monograf]. Center for Digital Society \& Institute of Governance and Public Affairs (IGPA) UGM.

Setten, G., \& Lein, H. (2019). "We draw on what we know anyway": The meaning and role of local knowledge in natural hazard management. International Journal of Disaster Risk Reduction, 38(101184), 1-8. https://doi.org/10.1016/j.ijdrr.2019.101184

Shapiro, J. (n.d.). Overview of Planning (Toolkit on Overview of Planning, pp. 1-52). CIVICUS.

Shortall, S., \& Shucksmith, M. (2001). Rural development in practice: Ussues arising in Scotland and Northern Ireland. Community Development Journal, 36(2), 122-133.

Shukla, P. Y. (2016). The Indian smart village: Foundation for growing India. International Journal of Applied Research, 2(3), 72-74.

Smith, T. A. (2011). Local Knowledge in Development (Geography). Geography Compass, 5, 595-609.

SMS Research \& Marketing Services, Inc. (2010). Rural economic development planning report (pp. 1-85). Economic Development Administration-US Department of Commerce.

Subekti, T., \& Damayanti, R. (2019). Penerapan Model Smart Village dalam Pengembangan Desa Wisata: Studi pada Desa Wisata Boon Pring Sanankerto Turen Kabupaten Malang. Journal of Public Administration and Local Governance, 3(1), 18-28.

Sultana, R., Muhammad, N., \& Zakaria, A. K. M. (2018). Role of indigeneous knowledge in sustainable development. International Journal of Development Research, 8(2), 1890218906.

Ŝūmane, S., Kunda, I., Knickel, K., Strauss, A., Tisenkopfs, T., Rios, I. des I., Rivera, M., Chebach, T., \& Ashkenazy, A. (2018). Local and farmers' knowledge matters! How integrating informal and formal knowledge enhances sustainable and resilient agriculture. Journal of Rural Studies, 59, 232-241. http://dx.doi.org/10.1016/j.jrurstud.2017.01.020

Surjono, Prasisca, Y., \& Sutikno, F. R. (2015). Gender Equality and Social Capital as Rural Development Indicators in Indonesia (Case: Malang Regency, Indonesia). Procedia Social and Behavioral Sciences, 211, 370 - 374. https://doi.org/doi: 10.1016/j.sbspro.2015.11.048

Szymańska, D., \& Chodkowska-Miszczuk, J. (2011). Endogenous resources utilization of rural areas in shaping sustainable development in Poland. Renewable and Sustainable Energy Reviews, 15, 1497-1501. https://doi.org/doi:10.1016/j.rser.2010.11.019

Taylor, B., \& de Loë, R. C. (2012). Conceptualizations of local knowledge in collaborative environmental governance. Geoforum, 43, 1207-1217. http://dx.doi.org/10.1016/j.geoforum.2012.03.007

Tiwari, S., Lane, M., \& Alam, K. (2019). Do social networking sites build and maintain social capital online in rural communities? Journal of Rural Studies, 66, 1-10. https://doi.org/10.1016/j.jrurstud.2019.01.029 
Un, C. A., \& Rodríguez, A. (2018). Local and Global Knowledge Complementarity: R \& D Collaborations and Innovation of Foreign and Domestic Firms. Journal of International Management, 24, 137-152. http://dx.doi.org/10.1016/j.intman.2017.09.001

UNESCO. (2017). Local Knowledge, Global Goals (pp. 3-45). UNESCO.

United Nations. (n.d.). Strategic Planning. Guide for Managers (pp. 2-15).

van Aswegen, M., \& Retief, F. P. (2020). The role of innovation and knowledge networks as a policy mechanism towards more resilient peripheral regions. Land Use Policy, 90(104259), 1-12. https://doi.org/10.1016/j.landusepol.2019.104259

van der Ploeg, J. D. (2000). Revitalizing Agriculture: Farming Economically as Starting Ground for Rural Development. Sociologia Ruralis, 40(4), 491-511.

van der Ploeg, J. D., Renting, H., Brunori, G., Knickel, K., Mannion, J., Marsden, T., de Roest, K., Sevilla-Guzmán, E., \& Ventura, F. (2000). Rural Development: From Practices and Policies towards Theory. Sociologia Ruralis, 40(4), 391-408.

van der Ploeg, J. D., \& Roep, D. (2003). Multifunctionality and rural development: the actual situation in Europe. In Multifunctional Agriculture; A new paradigm for European Agriculture and Rural Development (G. van Huylenbroeck and G. Durand, pp. 1-15). Ashgate, Hampshire,

van der Ploeg, J. D., Ye, J., \& Schneider, S. (2015). Rural development: Actors and practices. Constructing a New Framework for Rural Development. Research in Rural Sociology and Development, 22, 17-30. https://doi.org/doi:10.1108/S1057-192220150000022001

Wallerstein, N., \& Bernstein, E. (1994). Introduction to Community Empowerment, Participatory Education and Health. Health Education Quarterly, 21(2), 141-148.

Warren, D. M., \& Rajasekaran, B. (1993). Putting local knowledge to good use. International Agricultural Development, 13(4), 8-10.

Wegs, C., Creanga, A. A., Galavotti, C., \& Wamalwa, E. (2016). Community Dialogue to Shift Social Norms and Enable Family Planning: An Evaluation of the Family Planning Results Initiative in Kenya. PLoS ONE, 11(4), 1-23. https://doi.org/doi:10.1371/ journal.pone. 0153907

Wheatley, A., Christman, S. T., \& Nicolas, G. (2012). Walking the talk: Reflections from a Community-Focused Dialogue Series. Journal for Social Action in Counseling and Psychology, 4(1), 1-17.

Woolrych, R., Gibson, N., \& Sixsmith, A. (2015). "No Home, No Place": Addressing the Complexity of Homelessness in Old Age Through Community Dialogue. Journal of Housing For the Elderly, 29(3), 233-258. https://doi.org/DOI: 10.1080/02763893.2015.1055024

World Bank. (1998). Indigenous knowledge for development. A framework for action (pp. 142). Knowledge and Learning Center Africa Region World Bank.

Wu, B. (2015). Study on Rural Human Resource Development under View of Rural Regional Economic Development. 377-385. 